\title{
The Biographies of Bodily Ornaments from Indigenous Settlements of the Dominican Republic (AD 800-1600)
}

\author{
Catarina Guzzo Falci (D, Dominique Ngan-Tillard, Corinne L. Hofman, and Annelou Van Gijn
}

\begin{abstract}
In this study, we generate novel insights regarding bodily ornaments from indigenous societies of late precolonial Greater Antilles. Previous research has highlighted the sociopolitical role of valuable, exotic, and figurative ornaments, yet there are many gaps in our current understanding of these artifacts. Here, we focus on ornaments from five recently excavated sites in the Dominican Republic (AD 800-1600). We used microwear analysis to investigate each ornament and assess its production sequence and use life. These data permitted the definition of morpho-technical groups, which we then compared to depositional contexts and the regional availability of raw materials. We demonstrate that (1) there was small-scale production of ornaments at the sites, (2) the most recurrent morpho-technical groups were likely imported from production centers, and (3) ornaments of the same group could lead different use lives and be deposited through varied processes. We conclude that bodily ornaments had highly diverse biographies involving local and regional interaction networks.
\end{abstract}

Keywords: stone beads, shell ornaments, microwear analysis, micro-CT, object biography, Caribbean archaeology

El presente estudio se centra en los adornos corporales indígenas de finales del período precolombino en las Antillas Mayores. El rol sociopolítico de los ornamentos figurativos realizados en materiales de valor o exóticos ha tenido un papel destacado en investigaciones anteriores. A pesar de la abundancia de estudios, poco se conoce acerca de estas piezas. En este trabajo presentamos el análisis de los adornos corporales de cinco yacimientos arqueológicos recientemente excavados en la República Dominicana (800-1600 dC). Para el análisis de cada artefacto se empleó la traceología, con el objetivo de comprender la secuencia de producción y utilización. Se definieron grupos morfo-tecnológicos los cuales fueron relacionados con los contextos de deposición y con la disponibilidad regional de materias primas. Los resultados muestran que (1) existió una producción local a pequeña escala de adornos en los sitios, (2) los grupos morfo-tecnológicos más frecuentes probablemente fueron importados desde los centros de producción y (3) los adornos pertenecientes a un mismo grupo pudieron ser utilizados de modos variados y ser depositados mediante diferentes procesos. Se concluye que los adornos corporales tenían biografías diversas que involucraban redes de interacción locales y regionales.

Palabras clave: cuentas líticas, adornos en concha, traceología, micro-tomografía, biografía de los objetos, arqueología del Caribe

$\mathrm{T}$ The adornment of the body among Greater Antillean indigenous societies was notably diverse at the time of first contact with Europeans (from AD 1492). It encompassed body paint; feather garments; beaded necklaces and armlets; arm-, ankle- and headbands; embroidered belts and skirts; nose rings; earrings; and ear plugs (Alegría 1995; Fewkes
1903; García Castañeda 2012; Lóven 1935). Early historical accounts have provided privileged lenses through which these practices have been interpreted, with emphasis often placed on the Taíno cacicazgos, or chiefdoms, described by the Spaniards (Curet 1996, 2014; Keegan 2013; Keegan and Hofman 2017: 11-14; Rouse 1992; Siegel 2010; Wilson

Catarina Guzzo Falci (c.guzzo.falci@arch.leidenuniv.nl, corresponding author), Corinne L. Hofman, and Annelou Van Gijn $\square$ Faculty of Archaeology, Leiden University, Einsteinweg 2, Leiden, 2333 CC, The Netherlands

Dominique Ngan-Tillard a Faculty of Civil Engineering and Geosciences, TU Delft, Stevinweg 1, Delft, 2628 CN/2600 GA, The Netherlands

Latin American Antiquity 31(1), 2020, pp. 180-201

Copyright $(2020$ by the Society for American Archaeology. This is an Open Access article, distributed under the terms of the Creative Commons Attribution licence (http://creativecommons.org/licenses/by/4.0/), which permits unrestricted re-use, distribution, and reproduction in any medium, provided the original work is properly cited.

doi:10.1017/laq.2019.101 
2007). For instance, gift giving of stone beads and plates of gold-copper alloy (guanín) was allegedly crucial in the maintenance of sociopolitical order, alongside intermarriage between high-status individuals (Lóven 1935:478-479). Furthermore, the religious beliefs of Hispaniolan societies described by Fray Ramón Pané in 1498 have served as the basis for interpreting pendants thought to depict mythical characters (Alegría 1995; Arrom 1975; Fewkes 1903; McGinnis 1997; Maciques Sánchez 2018). The provenance, manufacture, and sociopolitical role of gold and guanín ornaments have been the focus of considerable research (Lóven 1935; Martiñón Torres et al. 2012; Oliver 2000; Vega 1979). An aesthetic of brilliance (Saunders 1999) has been used to explain the indigenous appreciation for certain materials, which would have differed markedly from European monetary systems of valuation (Berman 2011; Helms 1987; Keehnen 2012; Oliver 2000; Ostapkowicz 2018). Such interpretations have stressed the supernatural character of certain materials, such as guanin, mother-of-pearl, and feathers, as expressed in their exoticness, colors, and reflectance. The adornment of the body would display the political and shamanic powers of the cacique (Oliver 2000).

This reasoning has also been extended to less visually conspicuous ornaments, particularly stone beads and pendants from the Late Ceramic Age (AD 800-1492). Nevertheless, it seems paradoxical to include such ornaments in a narrative about the power of exotic and brilliant things, given that their raw materials are dull and widely available. Furthermore, concepts such as "Taíno" have been criticized as artificial labels that obscure the indigenous diversity of the region and simplify the complex relationships that communities maintained with each other (e.g., Curet 2014; Hofman et al. 2018; Keegan 2013; Keegan and Hofman 2017:239-249; Rodríguez Ramos 2010:200-203; Torres Etayo 2008; Ulloa Hung 2013; Wilson 1993, 2007). If ornaments were linked to high-status individuals, this exclusive access should be reflected archaeologically, and yet ornaments have seldom been recovered with the deceased. An exception is the site of El Chorro de Maíta (Cuba), where hundreds of ornaments were associated with a burial (Valcárcel Rojas 2012:108-121; see also Oliver 2000:201-202). Caches with hundreds of ornaments have also been found inside ceramic and wooden bowls in Puerto Rico (Fewkes 2009 [1907]:109; Ostapkowicz 2018) and the Dominican Republic (Ortega 2005:240-244; Ortega and Fondeour 1976; Vega 1979). Our knowledge about the biographies of ornaments is otherwise very limited. It has been argued that certain artifacts, such as cemí idols and greenstone celts, acquired their social status as a result of their biographies, involving investment in manufacture, reputation, or antiquity (Breukel 2019; Oliver 2009:255). In this perspective, only thorough examinations of ornaments can allow us to assess how people interacted with them. Here we apply microwear analysis to ornaments from five recently excavated archaeological sites across the Dominican Republic (Table 1; Figure 1), where they were predominantly recovered from domestic contexts. This study allows us to pursue these ornaments' biographies among indigenous Caribbean communities during the late precolonial period.

\section{Biographies of Ornaments}

Previous studies of ornaments have emphasized their symbolic and communicative roles when added to the human body. This perspective has prioritized the meaning of visual aspects of finished ornaments and raw materials. Archaeologists have more recently moved away from the pursuit of meaning in material culture to focus instead on its active potencies in society (e.g., Hodder 2011; Jones 2004; Malafouris 2008). Here, we propose a biographical approach as a means to move past a view of ornaments as passive and unchanging repositories of meaning. In its original proposition, the concept of object biography was connected to the oscillation of objects between different spheres of consumption (Kopytoff 1986). The entrance into new social contexts could lead to changes in meaning and expectations surrounding an object (Gosden and Marshall 1999; Joy 2009).

The study of archaeological artifacts requires a more holistic and empirical approach to the biography concept (Van Gijn and Wentink 2013). The biography of an artifact can be 
Table 1. Archaeological Sites Referenced in Text, Excavation Details, and Ornament Collections.

\begin{tabular}{|c|c|c|c|c|c|c|c|c|}
\hline \multirow[b]{2}{*}{ Site } & \multirow[b]{2}{*}{ Municipality } & \multirow[b]{2}{*}{ Province } & \multirow[b]{2}{*}{ Region } & \multirow{2}{*}{$\begin{array}{c}\text { Occupation } \\
\text { (Centuries AD) }\end{array}$} & \multirow{2}{*}{$\begin{array}{l}\text { Ostionoid } \\
\text { Subseries }\end{array}$} & \multirow{2}{*}{$\begin{array}{l}\text { Excavated } \\
\text { Area }\left(\mathrm{m}^{2}\right)\end{array}$} & \multicolumn{2}{|c|}{$\begin{array}{c}\text { Studied } \\
\text { Ornaments }\end{array}$} \\
\hline & & & & & & & $N$ & $\%^{\mathrm{a}}$ \\
\hline El Flaco & $\begin{array}{l}\text { Loma de } \\
\text { Guayacanes }\end{array}$ & Valverde & Northwest & $\begin{array}{l}\text { Thirteenth- } \\
\text { fifteenth } \\
\text { Tenth }\end{array}$ & $\begin{array}{l}\text { Mixed Chican and } \\
\text { Meillacan } \\
\text { Ostionan }\end{array}$ & 1,256 & 162 & 51.92 \\
\hline El Carril & Laguna Salada & Valverde & Northwest & $\begin{array}{l}\text { Eleventh- } \\
\text { fourteenth }\end{array}$ & $\begin{array}{l}\text { Meillacan with } \\
\text { other styles } \\
\text { mixed }\end{array}$ & 354 & 18 & 5.77 \\
\hline La Luperona & Unijica & Puerto Plata & Northwest & Thirteenth & Meillacan & 120 & 7 & 2.24 \\
\hline $\begin{array}{l}\text { Playa } \\
\text { Grande }\end{array}$ & Río San Juan & $\begin{array}{l}\text { María } \\
\text { Trinidad } \\
\text { Sánchez }\end{array}$ & North & $\begin{array}{l}\text { Ninth- } \\
\text { seventeenth }\end{array}$ & $\begin{array}{l}\text { Ostionan, } \\
\text { Meillacan, } \\
\text { Chican }\end{array}$ & 500 & 31 & 9.93 \\
\hline El Cabo & $\begin{array}{l}\text { El Cabo de San } \\
\text { Rafael }\end{array}$ & La Altagracia & East & $\begin{array}{l}\text { Ninth-sixteenth } \\
\text { Sixth-eleventh }\end{array}$ & $\begin{array}{l}\text { Chican } \\
\text { Ostionan }\end{array}$ & 1,164 & 94 & 30.13 \\
\hline
\end{tabular}

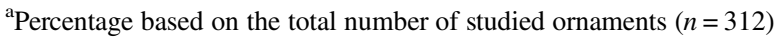
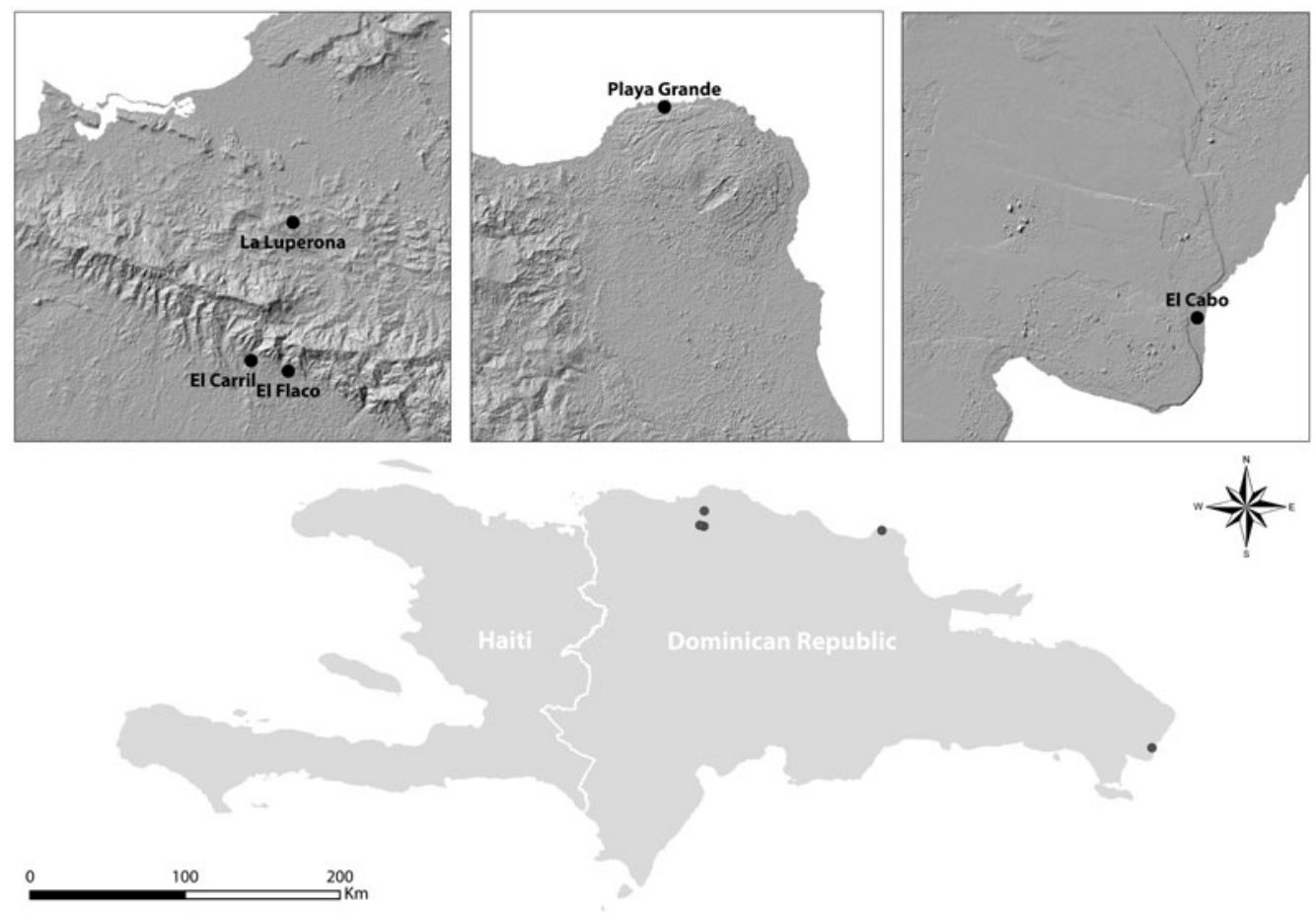

Figure 1. Map of Hispaniola with studied sites plotted. (Map by Eduardo Herrera Malatesta.)

assessed through the study of its multiple stages: conceptualization or design, raw material acquisition, manufacture, its addition to an assemblage, (re)use, recycling, fragmentation, and deposition (Van Gijn 2010). Understood in such a way, a biographical approach allows us to address the ways people physically interacted with materials. By tracking the ways in which ornaments were transformed, we can begin to explore their past social roles. A first step in this direction involves a focus on the chaîne opératoire of ornaments (Balfet 1991; Cresswell 
1983; Leroi-Gourhan 1993 [1964]). This approach provides a window into the choices made in the past regarding material properties and qualities, production sequences, techniques, tool kits, and gestures (Lemonnier 1993; Sillar and Tite 2000). This type of research also offers insights into the technical stages at which materials reached an archaeological site and were discarded (Perlès 2007). This can ultimately inform us about networks of material acquisition and exchange.

A technological approach needs to be supplemented by use-wear investigations, which have proved to be an important avenue for understanding how ornaments were (re)used, fragmented, or cared for (Van Gijn 2010, 2017; Woodward 2002; Woodward and Hunter 2015). Depositional contexts, such as burials, have offered extensive evidence regarding the compositions in which individual beads were attached and their association with certain social categories (e.g., Bonnardin 2012; Cristiani and Borić 2012; Hommel and Sax 2014). It is through the combination of different empirical lines of evidence that we can reconstruct the biographies of Late Ceramic Age ornaments.

\section{Archaeological Contexts}

\section{Northwestern Region}

Recent archaeological surveys across northwestern Dominican Republic have identified a diverse and interconnected sociocultural landscape (Hofman et al. 2018; Ulloa Hung 2013; Ulloa Hung and Herrera Malatesta 2015). Ongoing archaeological research focuses on late precolonial and early colonial sites along the route Christopher Columbus followed in 1494 from La Isabela, the first Spanish town in the New World, to the Cibao Valley (Hofman et al. 2016, 2018; Hofman and Hoogland 2015). The majority of ornaments described in this article were recovered from three open-air sites along this route.

El Flaco is a midsize settlement situated on the southern slopes of the Cordillera Septentrional about $20 \mathrm{~km}$ from the present coast. The site presents an occupation pattern characteristic of the northwestern region, which involves intentional modifications to the landscape to create flat areas for the placement of houses and other roofed structures (Hofman and Hoogland 2015; Sonnemann et al. 2016; Ulloa Hung 2013; Veloz Maggiolo and Ortega 1980). These flat areas are typically devoid of archaeological material, given that most domestic refuse has been "swept" aside, forming mounds. These mounds present evidence for the burning of garbage, human and dog burials, and food preparation on hearth structures. The lithic collection comprises greenstone celts, hammer stones, and decorated pestles. The celts were mostly imported to the site, with limited local production (Breukel 2019). Flint and quartz remains are nearly absent.

El Carril is currently under investigation and has thus far presented a similar pattern of landscape management (Hofman 2017; Hofman et al. 2018; Sonnemann et al. 2016). The settlement is located $2 \mathrm{~km}$ from El Flaco; a larger settlement, it has 102 mounds recorded to date (Hofman 2017; Veloz Maggiolo et al. 1981). La Luperona is located on the northern slopes of the Cordillera Septentrional, $8 \mathrm{~km}$ distant from El Flaco and $12 \mathrm{~km}$ from the coast (Hofman et al. 2016). The site differs in its spatial organization in that no mounds were recorded.

\section{Playa Grande}

Excavations at the site of Playa Grande, located on the northern Dominican coast, have exposed house plans, refuse middens, hearth structures, and potential agricultural mounds (López Belando 2012; Veloz Maggiolo and Ortega 1980:42-45). Multiple occupation phases have been identified, including mixed indigenous and Spanish material culture on the upper layers (López Belando 2012). The inhabitants of the site were engaged in the production and regional exchange of greenstone celts, notably of jadeitite - a rare lithic material, the geological source of which is located $20-30 \mathrm{~km}$ to the southwest of Playa Grande (Breukel 2019; Knippenberg 2012; Schertl et al. 2018). Other recovered lithic tools include flint flakes, grooved grinding stones of sandstone, hammer stones, polishing stones, and pestles (Knippenberg 2012).

\section{El Cabo}

The eastern tip of the Dominican Republic was a densely occupied region in the late precolonial 
period (Ortega 1978, 2005; Samson 2010; Samson and Hoogland 2007). The site of El Cabo is located on a coastal promontory overlooking the Mona Passage, which separates Hispaniola from western Puerto Rico (Hofman et al. 2008, 2014; Samson 2010; Samson and Hoogland 2007). The earliest occupation, situated on the north of the site, is characterized by ring-shaped midden deposits. The later occupation, situated to the south, continued until about AD 1504, as indicated by associated Spanish material (Keehnen 2012). Postholes dug into the limestone bedrock enabled the reconstruction of 30 house plans, the establishment of a typology of structures, and insight into the periodical rebuilding of house structures over centuries of occupation (Samson 2010, 2011). Recovered nonceramic artifacts include carved lithic and shell artifacts, greenstone celts, and flint and quartz flakes (Breukel 2019; Samson 2010). In addition, a cache with more than 4,000 canine teeth pendants was recovered from a nearby water spring (Ortega 2005:115116).

\section{Methods}

In archaeological contexts without production debris, only limited information can be gathered from observing ornaments with the naked eye. This is because finished ornaments are highly modified and do not preserve clear evidence of their production stages. Microwear analysis offers the possibility of identifying traces formed on the surface of a bead during its lifetime. We examined all potential ornaments to which we had access, and those specimens positively identified as ornaments were analyzed for microwear $(n=312)$. Analysis was carried out in the Dominican Republic or at Leiden University. Different microscope models were used according to the research setting: DinoLite digital microscopes (magnification: 20-60x), a Leica M80 stereomicroscope (7.5-64x), and a Leica DM6000M and a Nikon Optiphot metallographic microscope (50-500x). An experimental archaeology program was carried out to provide reference materials for the interpretation of tools and techniques used in ornament making (Breukel and Falci 2017; Falci et al. 2017;
Supplemental Table 1; Figure 2a-o). For the interpretation of use-wear, we referred to our previous study of ethnographic composite ornaments (Falci et al. 2018) and to published experiments (e.g., Mărgărit 2016; Vanhaeren et al. 2013). The results of this analysis provided the basis for grouping ornaments into morphotechnical groups (Table 2).

We also used a desktop X-ray $\mu$-CT scanner to image the inner structures of 10 beads in 3D. Several researchers (Gu et al. 2014; Ngan-Tillard et al. 2018; Yang et al. 2018) have proven the added value of $\mu$-CT scans in the study of ornaments made of diverse materials, such as lithic, ceramic, shell, and glass artifacts. Scans reveal the morphology of bead perforations, which are difficult to examine using optical microscopy. The resolution of the scans (5-10 micrometers for a $10 \mathrm{~mm}$ diameter bead) is sufficient to observe features related to the manufacturing process and use. We selected for scanning beads of different raw materials or with double perforations. Here we include a qualitative assessment of the perforations reconstructed digitally. We offer a preliminary interpretation that contrasts the scanned archaeological specimens (Figure $3 \mathrm{a}-\mathrm{j}$ ) to silicone casts of the materials drilled during the experiments.

\section{Results}

Bodily ornaments were most commonly made of lithic raw materials, particularly calcite and plutonic rocks (Supplemental Table 2). Calcite is a carbonate mineral, characterized by low hardness ( 3 in Mohs scale) and relative ease of work using abrasive techniques. Beads and pendants made of this material have low translucency and a white color (Figure $4 a-q$ ). Plutonic rocks are medium to hard rocks that are generally tough, heterogeneous, and coarse grained (Figure 5a-r). They are composed of mafic and felsic minerals, displaying a mottled white and black or green color. Other lithic materials were also made into varied ornament types (Figure 6a-o). Hispaniola has a diverse geological makeup (Draper et al. 1994), with calcite and plutonic rocks fairly common across the island. Small to medium pebbles can be collected from riverbeds in the northwestern region, such 

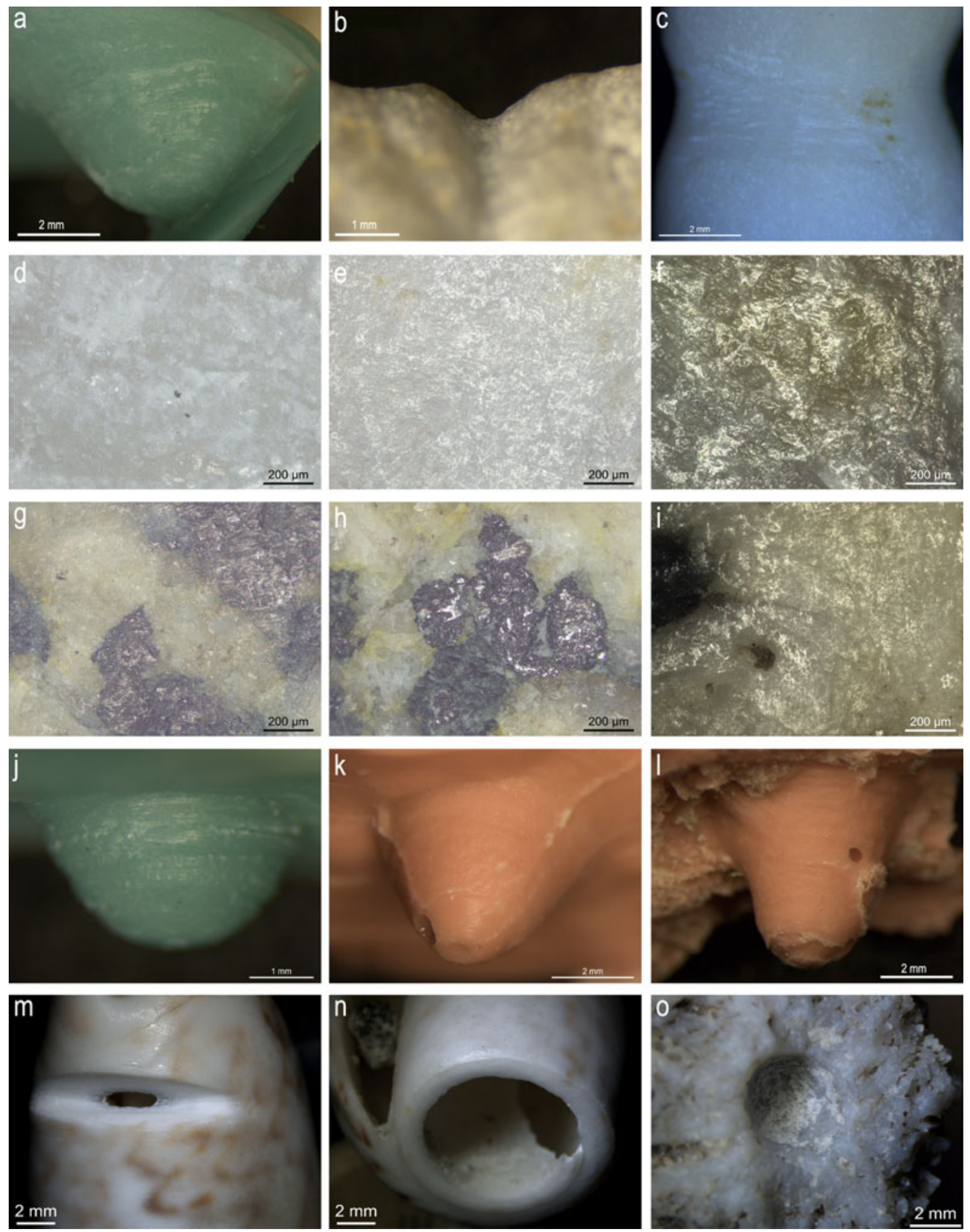

Figure 2. Experiments with calcite (a-f), diorite (g-i), Lobatus gigas $(\mathbf{j}, \mathbf{k})$, Spondylus americanus $(\mathbf{l})$, Oliva reticularis $(\mathbf{m}, \mathbf{n})$, and Acropora cervicornis (o). (Color online)

as from the Yaque del Norte and the Bahabonico Rivers. Because of their regional ubiquity, tracing their geological sources with geochemical techniques is challenging. Only at El Cabo can we argue that plutonic rocks originated from elsewhere, because carbonates and volcanics predominate on eastern Hispaniola (Draper et al. 1994).

Many ornaments were produced using marine resources, including varied mollusk shells (Figure 7a-u), corals (Figure 8a-b), and fish skeletal materials (Figure 8c-e). Seashells were 
Table 2. Number of Ornaments in Each Morpho-Technical Group Divided according to Archaeological Site.

\begin{tabular}{|c|c|c|c|c|c|c|}
\hline Raw Material Groups & $\begin{array}{c}\text { El } \\
\text { Flaco }\end{array}$ & $\begin{array}{c}\text { La } \\
\text { Luperona }\end{array}$ & $\begin{array}{c}\text { El } \\
\text { Carril }\end{array}$ & $\begin{array}{c}\text { El } \\
\text { Cabo }\end{array}$ & $\begin{array}{c}\text { Playa } \\
\text { Grande }\end{array}$ & Total \\
\hline \multicolumn{7}{|l|}{ Calcite } \\
\hline $\begin{array}{l}\text { Group 1: double perforated tubular beads with hourglass } \\
\text { shape }\end{array}$ & 15 & 1 & 3 & 3 & - & 22 \\
\hline Group 2: disc beads & 32 & - & - & - & - & 32 \\
\hline Group 3: small barrel-shaped beads & 9 & - & - & - & - & 9 \\
\hline Group 4: Short and wide barrel-shaped beads & 4 & - & - & - & - & 4 \\
\hline Other beads & 5 & 1 & - & 3 & 1 & 10 \\
\hline Pendants & - & 2 & 1 & - & 1 & 4 \\
\hline \multicolumn{7}{|l|}{ Plutonic rocks } \\
\hline $\begin{array}{l}\text { Group 1: double perforated tubular beads with hourglass } \\
\text { shape }\end{array}$ & 1 & - & 1 & 2 & - & 4 \\
\hline $\begin{array}{l}\text { Group 2: short tubular beads with decorative side } \\
\text { perforations }\end{array}$ & 2 & 1 & - & 11 & 1 & 15 \\
\hline Group 3: double perforated tubular beads & 4 & - & 2 & 2 & 1 & 9 \\
\hline Group 4: disc beads with incisions on the sides & 6 & - & - & 9 & - & 15 \\
\hline Other beads & 3 & - & - & 1 & 7 & 11 \\
\hline Earplug & - & - & - & - & 1 & 1 \\
\hline Pendants & 1 & - & - & - & 1 & 2 \\
\hline \multicolumn{7}{|l|}{ Stalactite } \\
\hline Beads & - & - & 2 & - & - & 2 \\
\hline Earplug & - & - & - & 1 & - & 1 \\
\hline \multicolumn{7}{|l|}{ Other lithics } \\
\hline Beads & 9 & 1 & - & 3 & - & 13 \\
\hline Inlay & - & - & - & 1 & - & 1 \\
\hline Earplug & - & - & - & 1 & 3 & 4 \\
\hline Pendants & - & - & 1 & - & 1 & 2 \\
\hline \multicolumn{7}{|l|}{ Shell } \\
\hline "Seed beads" & 12 & - & - & 8 & - & 20 \\
\hline Disc beads & 1 & - & - & 1 & 3 & 5 \\
\hline Scaphopod shell beads & 10 & - & - & - & - & 10 \\
\hline Conus sp. apex beads & - & - & - & 2 & - & 2 \\
\hline Frog-shaped beads & - & - & 1 & 6 & - & 7 \\
\hline Tinklers & 12 & - & 2 & 11 & 1 & 26 \\
\hline Other automorphic shell pendants & 1 & - & 1 & 4 & 1 & 7 \\
\hline Flat nacre pendants & 3 & - & 1 & 2 & - & 6 \\
\hline Flat pendants and inlays & 7 & - & - & 18 & 1 & 26 \\
\hline Three-dimensional pendants and plugs & 2 & - & - & 1 & 6 & 9 \\
\hline \multicolumn{7}{|l|}{ Bone } \\
\hline Vertebrae beads & 5 & - & - & - & - & 5 \\
\hline Tubular bead & 1 & - & - & - & - & 1 \\
\hline Highly modified & - & 1 & 1 & - & - & 2 \\
\hline \multicolumn{7}{|l|}{ Teeth } \\
\hline Automorphic & 4 & - & - & - & 1 & 5 \\
\hline Ground and perforated & 3 & - & - & 1 & - & 4 \\
\hline \multicolumn{7}{|l|}{ Coral } \\
\hline Beads & 6 & - & 1 & 1 & - & 8 \\
\hline Disc & - & - & - & 1 & - & 1 \\
\hline \multicolumn{7}{|l|}{ Ceramic } \\
\hline Globular beads & 3 & - & - & - & - & 3 \\
\hline Incised bead & 1 & - & - & - & - & 1 \\
\hline \multicolumn{7}{|l|}{ Wood } \\
\hline Disc & - & - & 1 & - & - & 1 \\
\hline Earplug & - & - & - & - & 1 & 1 \\
\hline \multicolumn{7}{|l|}{ Resin } \\
\hline Earplug & - & - & - & 1 & - & 1 \\
\hline
\end{tabular}




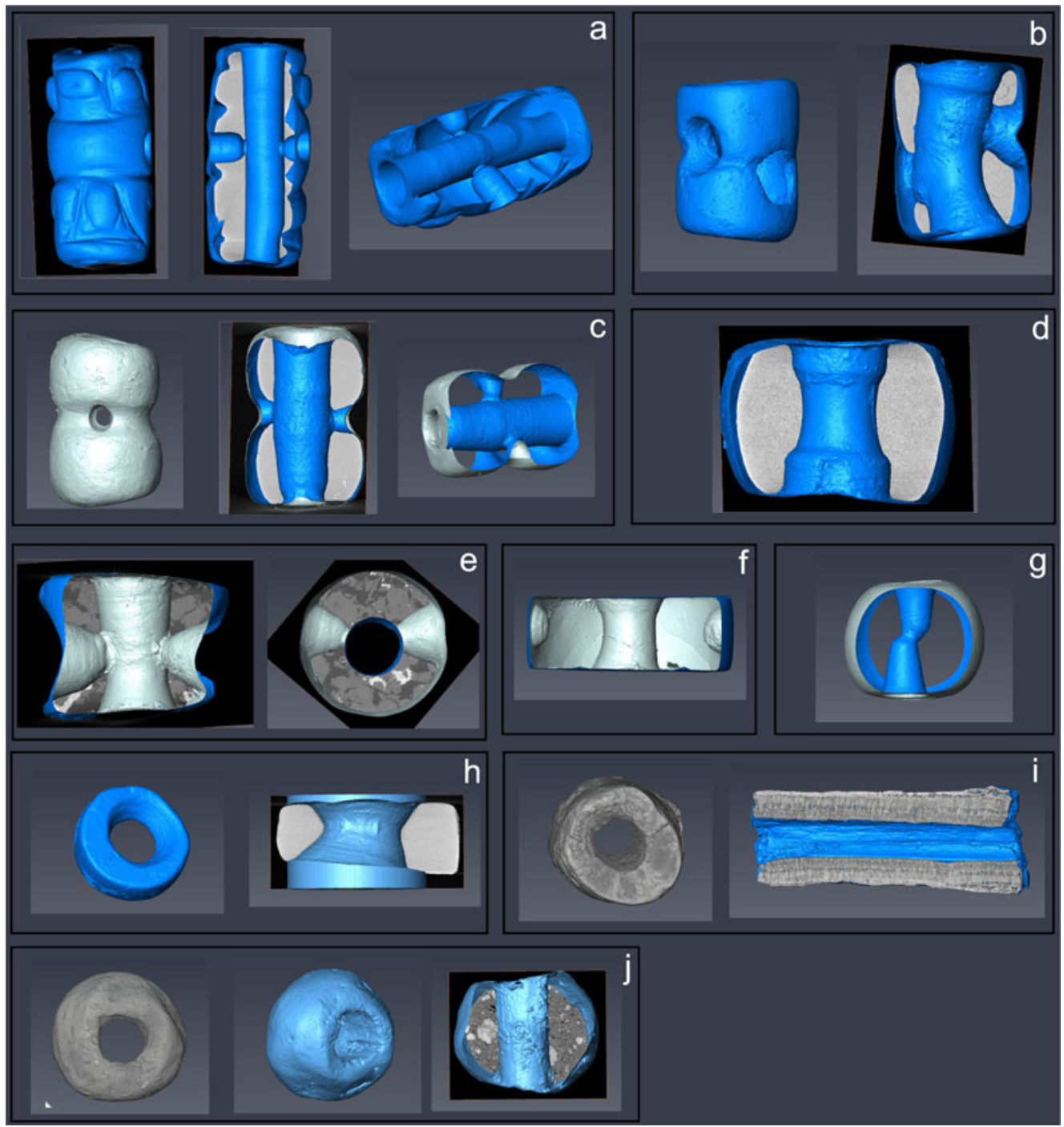

Figure 3. $\mu$-CT scans of beads: calcite group 1 (a-c), calcite group 4 (d), diorite group 2 (e, f), other lithic raw material (g), shell group $1(\mathrm{~h})$, coral (i), and pottery (j). (Color online)

the second most abundant raw material. Depending on the species, they provide tough, but relatively soft media (4 in Mohs scale) with a great variety of shapes and colors. The sites in the northwestern region are located at significant distances from the coast. Although marine resources contributed to the local diet (Hofman 2017), the species used for ornament production were not commonly retrieved as production debris or tools. In contrast, both Playa Grande and El Cabo are located on the coast, accounting for the larger percentages there of recovered shell artifacts.

\section{Production Technologies}

The collections recovered from the sites mainly comprise finished ornaments, with few preforms (7\%; Supplemental Table 3). Evidence for blank production and early reduction techniques is thus scarce. Most ornaments are well preserved, with only $31.7 \%$ displaying postdepositional surface modifications. Surface preservation of shell and certain lithic ornaments was notably poor at El Cabo $(n=46)$. In addition, 90 artifacts $(28.8 \%)$ were fragmented, with minor $(n=30)$ and major breakages $(n=34)$. Most breakages likely 

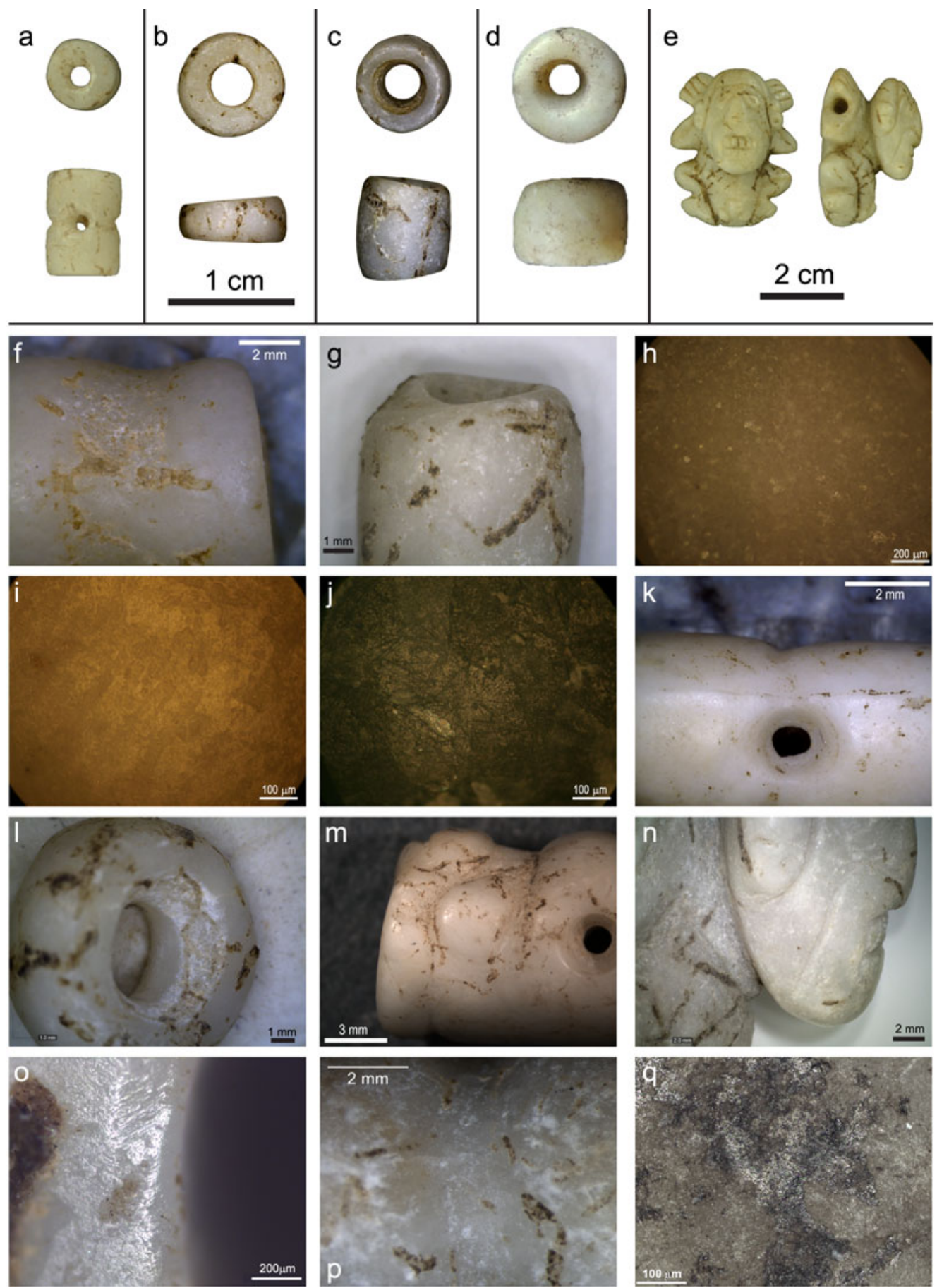

Figure 4. Calcite ornaments of groups 1 (a), 2 (b), 3 (c), 4 (d), and anthropomorphic pendant (e). Manufacture and use traces: sawing $(f, g)$, grinding $(h)$, polishing $(i, j)$, side perforation and central notch $(k)$, drilled cone in three stages $(\mathbf{l})$, anthropomorphic carvings $(\mathrm{m}, \mathbf{n})$, use-wear $(\mathbf{o}, \mathbf{p})$, and residue $(\mathbf{q})$. (Color online) 

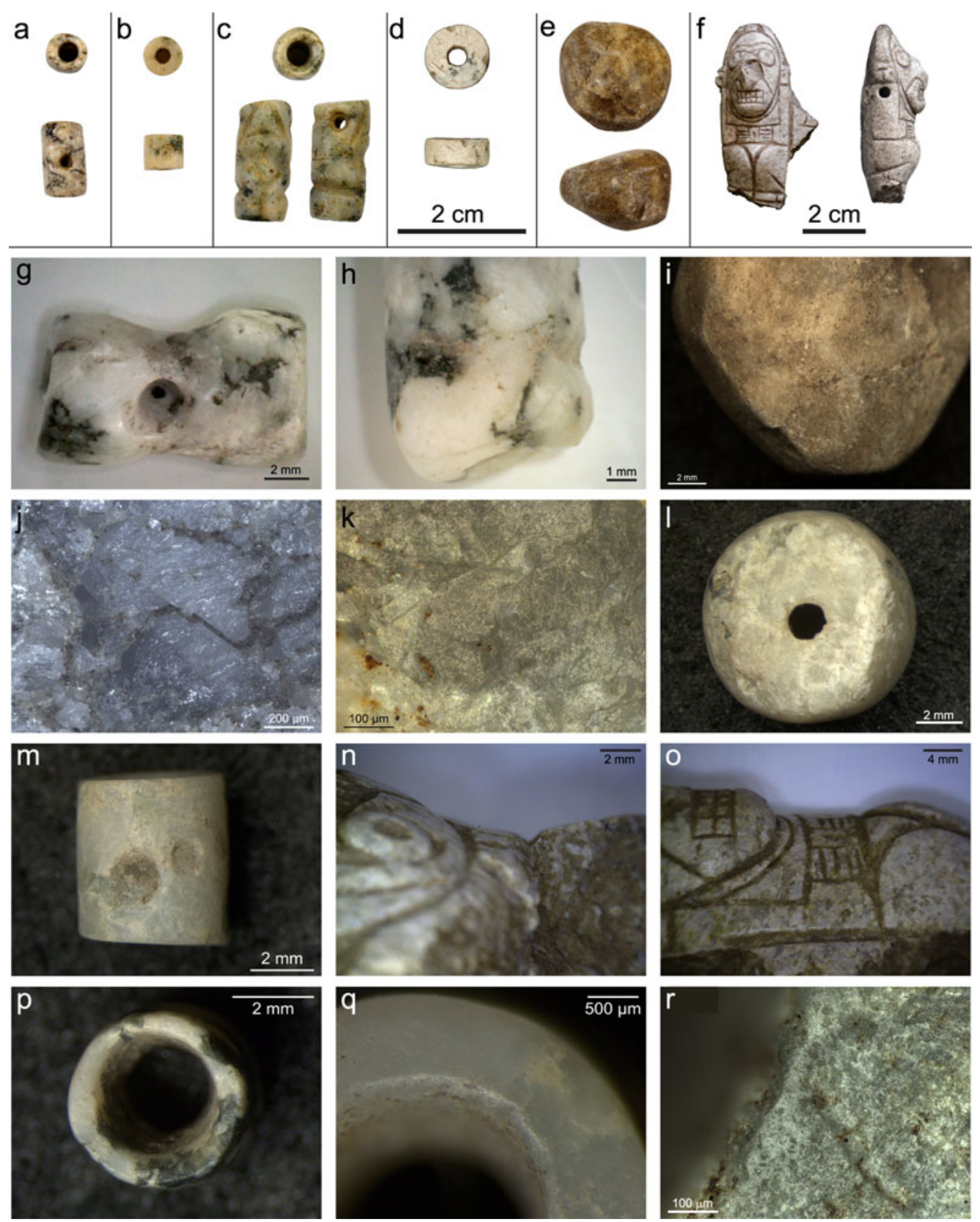

Figure 5. Plutonic rock ornaments of groups 1 (a), 2 (b), 3 (c), 4 (d), other (e), and anthropomorphic twin pendant (f). Manufacture and use traces: sawing and fresh side perforation (g), sawing and incision (h), sawing and snapping (i), grinding (j), polishing (k), pecking (l), unfinished side perforations (m), carvings (n, o), and use-wear on perforations (pr). (Color online)

happened before or during deposition $(n=83)$. The most frequently occurring morpho-technical groups are discussed in the following sections. Detailed data for each group are available in Supplemental Table 4.
Calcite. Calcite is the most prevalent lithic material in the studied sample, being predominantly used for bead production (Figure 4). Cut-and-break was identified as a blank acquisition technique on 11 artifacts (13.6\%), which 
a

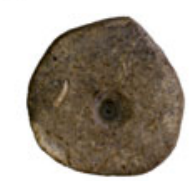

b

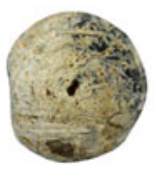

$2 \mathrm{~cm}$

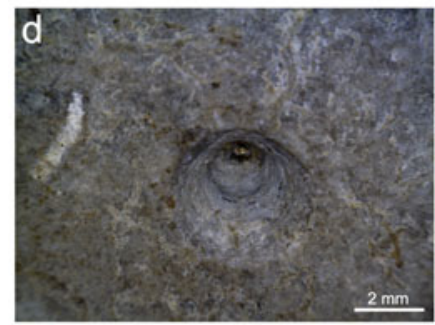

g
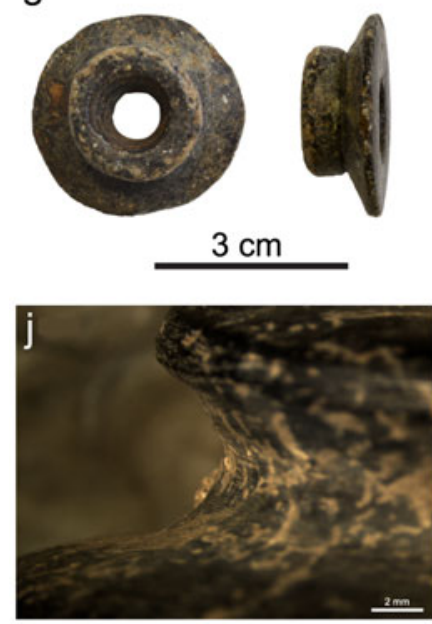
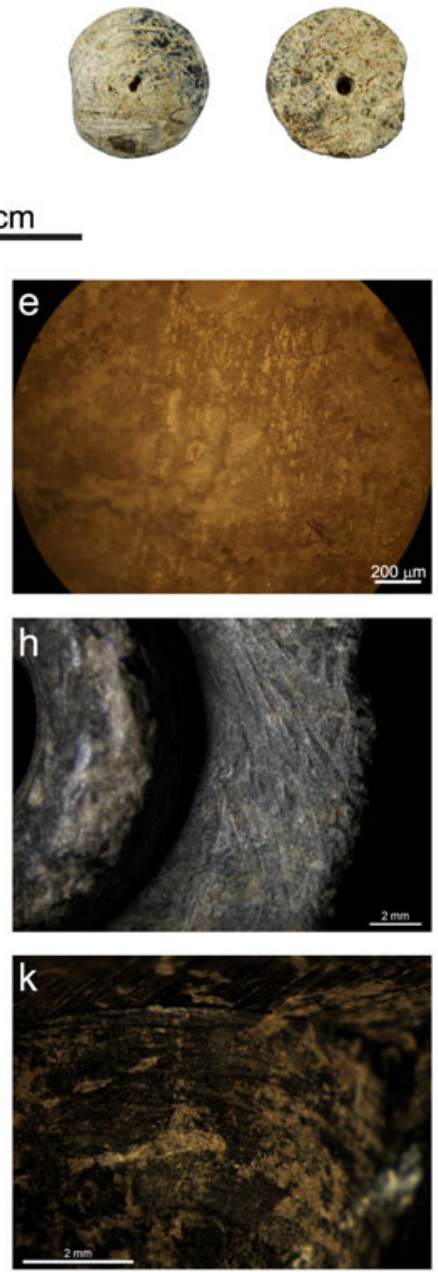
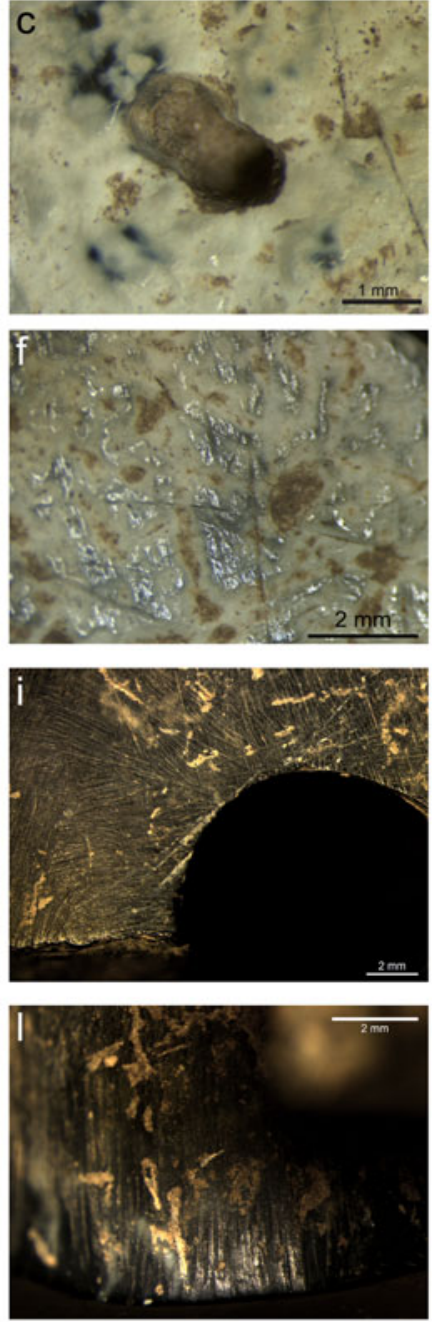

Figure 6. Bead preforms (a-f) and ear spools (g-l) made of diverse lithic materials with evidence for manufacture. (Color online)

displayed cut marks, a pronounced wedge shape resulting from a poor snapping of the blank, or both. The experiments carried out show that a calcite blank can be easily sawn with a flint flake. This technique offers the possibility of quickly obtaining bead blanks with good control. Pendants were likely produced from whole nodules or crystals, given that they are much larger than the beads.

Grinding is identifiable by coarse striations and by the presence of faceting. Using high magnification, we observed it on 27 specimens, being characterized by a flattened and dull surface, either with no clear polish or with polish restricted to the tops of the micro-topography, alongside bright bands of striations. Polishing was noted on most calcite ornaments $(n=52$; $64.2 \%$ ); it is characterized by a greasy and invasive polish, with some variability in roughness, number of pits, and striations. Polishing experiments were carried out using a dried high-silica leaf (Cecropia sp.) and a cane section from a palm (Sabal cf. domingensis). Some similarity between experiments and recovered artifacts is apparent in the invasiveness and general greasy appearance of the resulting polishes, in particular with the experiments produced with the cane. Despite this similarity, no direct correspondence 

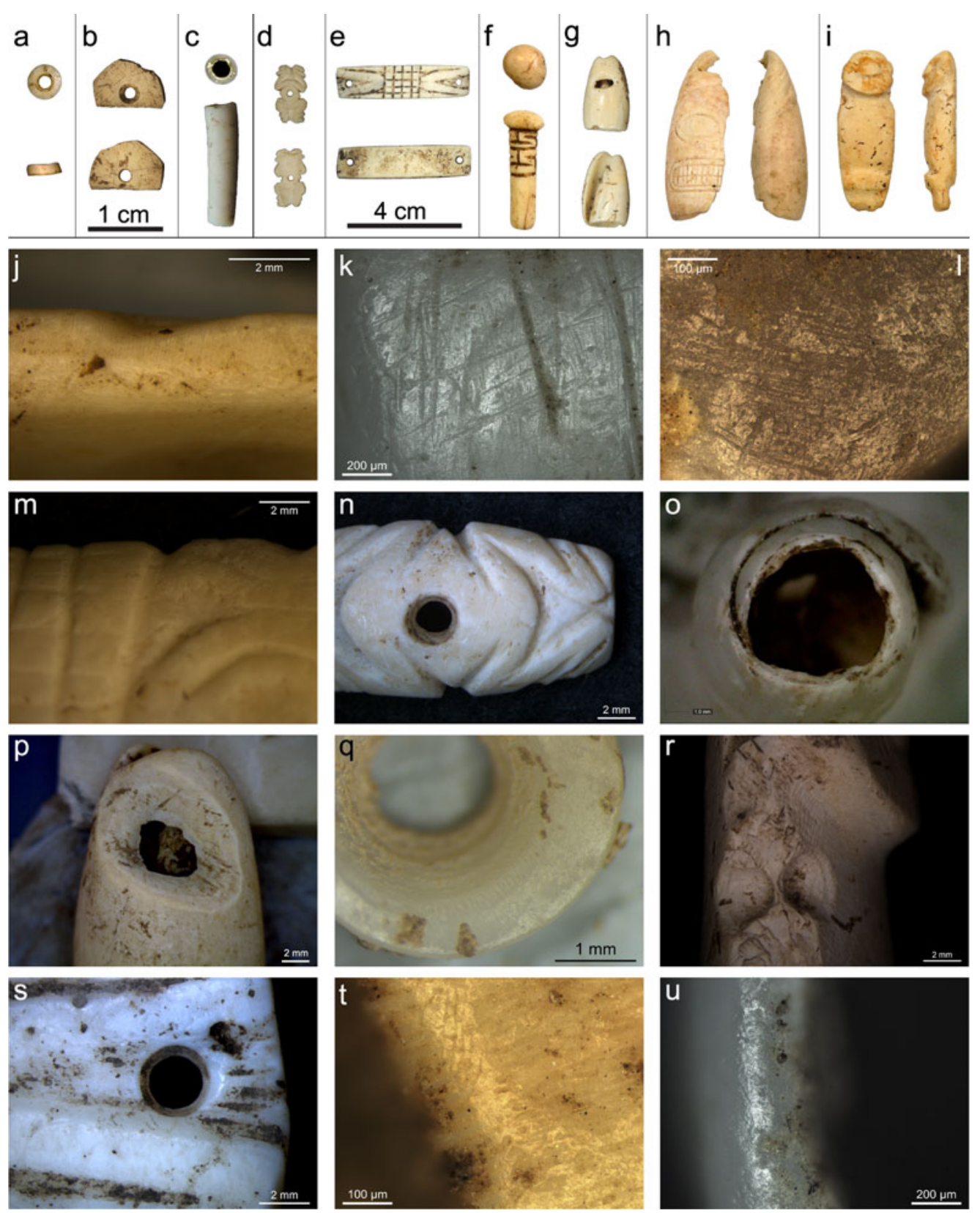

Figure 7. Shell ornaments: “seed bead" (a), disc bead (b), scaphopod bead (c), frog-shaped bead (d), plaque (e), conical plug (f), tinklers (g, h), and anthropomorphic pendant (i). Manufacture and use traces: sawing ( $\mathrm{j}, \mathrm{k})$, grinding (l), incising and notching $(\mathrm{m}, \mathrm{n})$, percussion to remove apex $(\mathrm{o})$, sawn perforation $(\mathbf{p})$, drilling $(q)$, incomplete drilling (r), and use-wear on perforations (s-u). (Color online)

was possible, in part because of the variability of polish characteristics observed and the interaction between the surface treatment, use-wear, and postdepositional processes. We thus attributed the observed surface treatment to a soft contact material, but we did not consider it to be not sufficiently distinctive for more precise identification.

All calcite ornaments were perforated with massive drill bits. (Bi-)cylindrical perforation 


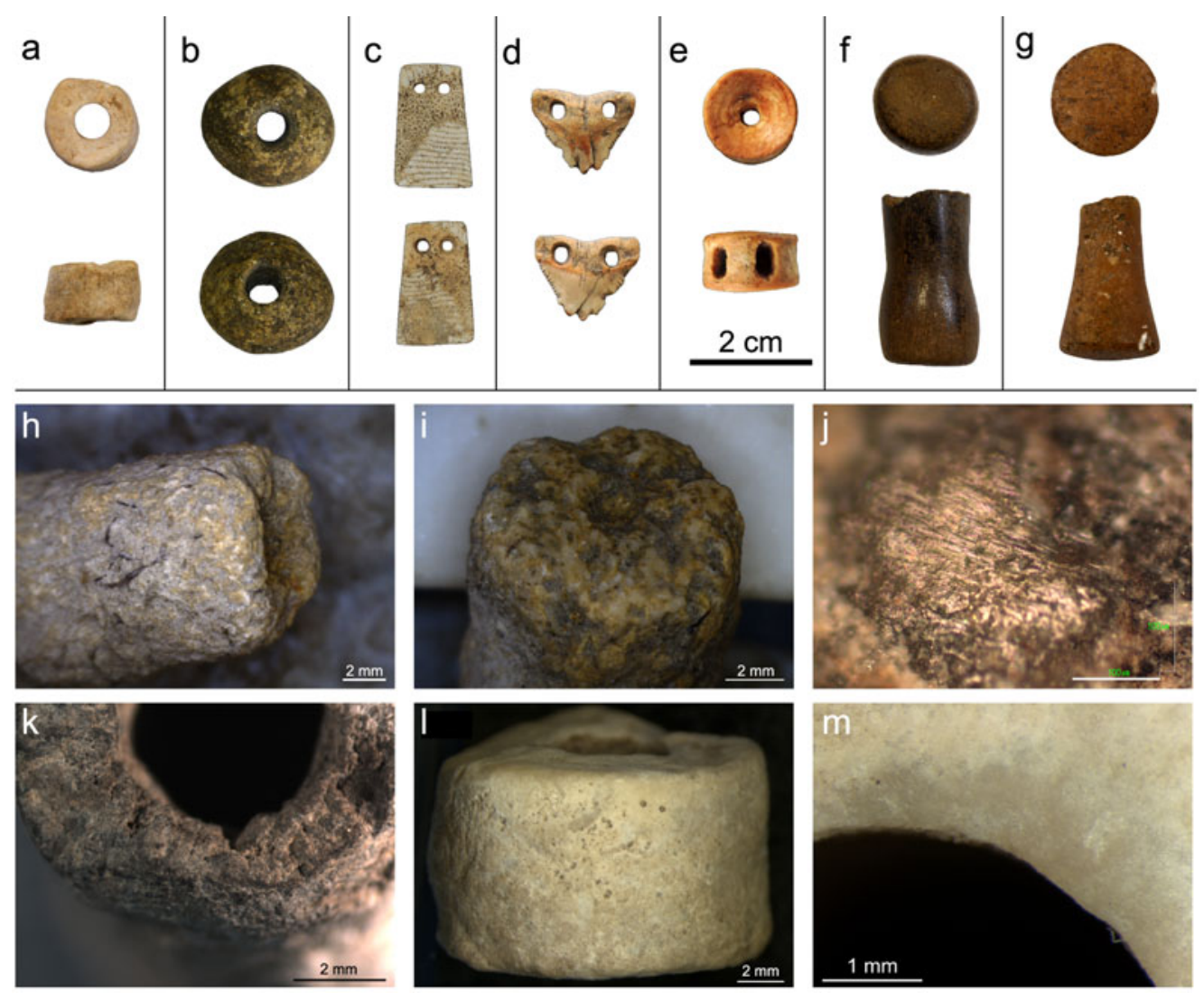

Figure 8. Ornaments of diverse raw materials with manufacture and use traces: coral beads (a, h-m), ceramic bead (b), pendants made of dental elements (c, d), wooden plug (f), and resin plug (g). (Color online)

profiles with circular grooves and scratches were observed on group 1 beads. These traces suggest that the craftsperson used a long and cylindrical drill bit, probably of organic origin, with abrasives. Drilling experiments with wooden and bone drills to perforate shells (which have a similar composition and hardness to calcite) show comparable perforations with no clear surface polish or scratches but occasional broad circular rings (Figure 2k-1). The end tip of the drilled hole can present polish and fine scratches because of the accumulation of abrasive material on the leading edge.

The drilling method used for group 1 involved two stages: (1) drilling a tubular bead predominantly from one face, thus producing a wide rim of perforation, and (2) drilling the opposite face, producing a small, conical perforation. Additionally, a second perforation was added to the sides of the beads, perpendicular to the first one. Investigation with the $\mu$-CT scan showed that side perforations are similar to the main ones and are therefore likely produced by the same tool kit (Figure 3a, c). In contrast, group 3 and the "other" group were drilled with brittle and hard lithic drill bits, as evidenced by biconical perforations with irregular concentric scratches (cf. Figure 2a). Group 2 disc beads displayed yet another drilling method, involving three stages: before biconical drilling with a hard lithic drill, they were perforated with a cylindrical drill bit, evidenced by a narrow and smooth cylindrical sector in between the two fresher cones. A comparable perforation is observed on a group 4 bead (Figure 3d). Group 1 beads were further modified by the addition of a groove on the side. This groove was made either with the thin edge of a brittle lithic flake, producing an incised line, or with a broader edge that produced a wider groove. Polishing took place after the 
creation of the grooves and side perforations, thus producing an hourglass shape. Six artifacts display anthropomorphic carvings made with hard and brittle lithic tools, which combine incision, notching, drilling, and bas-relief.

Plutonic Rock. Plutonic rock ornaments display greater morpho-technical variability (Figure 5a-r). Cut-and-break was identified on 10 beads $(17.5 \%)$. This technique is evident on poorly shaped bead preforms from Playa Grande, which were not extensively modified after sawing. Sawing diorite is a time-consuming task; to avoid mishaps, a deep groove needs to be sawn as a guide to snapping. Pecking was possibly used to remove sharp ridges, but diagnostic traces have been erased in all but two beads. Grinding traces were predominant on 24 ornaments $(42.1 \%)$, which are characterized by a dull and coarse surface. Polishing with a soft contact material was identified on 23 beads $(40.3 \%)$. Both treatments were observed in combination on nine ornaments. The main perforations were likely made with the same tool kit used for calcite group 1 beads (organic drill bits), given that bi-cylindrical profiles with circular grooves are common across all bead morphotechnical groups. In contrast, the side perforations, either complete holes or decorative pits (not pierced through), were produced with hard and brittle lithic tools. Decorative carvings are present on 23 ornaments $(40.4 \%)$, with the use of hard and brittle lithic tools identified on 10 ornaments. Four artifacts display biomorphic carvings made by a combination of incision, excision, and notching.

Other Lithic Materials. Beads, pendants, and an inlay were made of diverse materials, including stalactite $(n=2)$, limestone $(n=1)$, and "greenstones" $(n=4)$. Some of these beads do not fit any previously defined group, testifying to the existence of ornament biographies that are poorly represented at the sites. Two examples are the only lithic bead preforms recovered from El Flaco and El Cabo: a large and faceted disc bead (Figure 6a) and a plano-convex bead (Figure 6b). Both beads display misaligned and unfinished perforation cones (Figure 6, c-d) and rough grinding (Figure 6, e-f), having been abandoned before completion. The two beads are different from all other studied beads.
Plugs. Both conical and biconical plugs are represented, with a great variety in raw materials. Biconical plugs were likely ear spools, whereas T-shaped conical specimens could have been ear or lip plugs. The conical plugs were produced by a combination of grinding, sawing, and scraping to create different shapes varying from a marked T-shaped artifact (Figure 7f) to a nearly perfect cone (Figure $8 \mathrm{f}-\mathrm{g}$ ). Incised patterns were added to the surfaces of conical plugs made of stalactite and shell. The stone ear spools (Figure 6g-1), all from Playa Grande, were shaped in multiple stages: (1) grinding a thick circular blank in shape, (2) drilling a biconical perforation on its center, (3) sawing a notch around the sides with a V-shaped lithic tool, (4) widening the notch with a broad-edged tool, (5) smoothing the drilled hole with an abrasive tool, and finally (6) polishing with soft contact materials. Their dull surfaces, with preserved manufacture traces, suggest that certain specimens were discarded during production, but the small number of specimens and their fragmented nature limit interpretation.

Shell. Shell ornaments encompass great variability (Figure 7). One morpho-technical group includes 20 "seed beads"-very small disc beads made of different shell species: Lobatus gigas, Chama sarda, and an unidentified bivalve. The recurring diameters $(5-6 \mathrm{~mm})$ and perfectly circular shapes of the beads suggest some standardization of production, probably by grinding their sides on a mineral platform while strung together (Lammers-Keijsers 2007:64). The beads were individually perforated with tiny flakes of hard and brittle lithics.

Nine tubular beads were made from sections of tusk shell (Scaphopoda). They are hollow and slightly curved, with a smooth surface. Most beads display stepped fractures at the ends; in addition, cut marks or incisions left from blank acquisition are commonly seen (Figure 7c, k). Complete shells were not identified, although beads of different heights were retrieved from El Flaco. Their recurring diameters suggest a sustained preference for the least curved sector of the shell for bead making.

Flat and three-dimensional pendants, plaques, and inlays were produced with mollusk shell, often L. gigas. Different parts of the shell were 
Table 3. Use-Wear Presence per Archaeological Site.

\begin{tabular}{|c|c|c|c|c|c|c|c|c|c|c|c|c|}
\hline \multirow[b]{2}{*}{ Use-wear } & \multicolumn{2}{|c|}{ El Flaco } & \multicolumn{2}{|c|}{ El Carril } & \multicolumn{2}{|c|}{ La Luperona } & \multicolumn{2}{|c|}{ Playa Grande } & \multicolumn{2}{|c|}{ El Cabo } & \multicolumn{2}{|c|}{ Total } \\
\hline & $\mathrm{N}$ & $\%$ & $\mathrm{~N}$ & $\%$ & $\mathrm{~N}$ & $\%$ & $\mathrm{~N}$ & $\%$ & $\mathrm{~N}$ & $\%$ & $\mathrm{~N}$ & $\%$ \\
\hline Present & 100 & 61.73 & 13 & 72.22 & 7 & 100 & 15 & 48.39 & 66 & 70.21 & 201 & 64.42 \\
\hline Absent & 18 & 11.11 & 2 & 11.11 & - & - & 5 & 16.13 & 8 & 8.51 & 33 & 10.57 \\
\hline Half products ${ }^{\mathrm{a}}$ & 8 & 4.94 & 2 & 11.11 & - & - & 8 & 25.80 & 4 & 4.25 & 22 & 7.05 \\
\hline Indeterminate & 36 & 22.22 & 1 & 5.55 & - & - & 3 & 9.68 & 16 & 17.02 & 56 & 17.95 \\
\hline Total & 162 & 100 & 18 & 100 & 7 & 100 & 31 & 100 & 94 & 100 & 312 & 100 \\
\hline
\end{tabular}

${ }^{\mathrm{a}}$ Use-wear presence/absence is not applicable to half products, as they are not finished ornaments.

selected (e.g., lip or columella), depending on the desired volume and shape of the artifact. The blanks of both flat and three-dimensional artifacts were initially shaped through sawing. Next, they underwent grinding and biconical drilling with hard lithic drills. Flat ornaments received geometric patterns through incision and the creation of bas-relief, whereas threedimensional specimens underwent notching, incising, excising, and drilling. The combination of techniques allowed the carvers to create both anthropomorphic and zoomorphic figures.

Tinklers were carved on whole gastropod shells, particularly Oliva reticularis. Their production consisted of two operations: (1) removal of the apex of the shell through percussion (Figure 7o), grinding, or both and (2) perforation of the body whorl. In most cases, the perforation displays a U-shaped profile produced by sawing with a broad-edged lithic tool or with an organic tool, such as a wooden one, with abrasives (Figure 7p). Six specimens do not display a side perforation, being possibly unfinished. Four tinklers display incised and drilled carvings made with hard and brittle lithic tools, creating facial attributes or geometric patterns. $O$. reticularis shells were also used for the sawing of blanks for frog-shaped beads. These blanks were ground, drilled biconically with a hard and brittle lithic bit, and carved into a flat schematic frog by notching, incising, and creating bas-relief areas.

Stony Coral. Eight coral beads-most of which were made of Acropora cervicornis (Figure $8 \mathrm{a}, \mathrm{h}-\mathrm{m}$ )—were recovered from three sites. Two specimens have unfinished perforations, being interpreted as preforms. Unperforated branches of A. cervicornis were also recovered. One bead displays cut marks close to its edge, possibly linked to the splitting of the branches in small sections. The beads were drilled and sometimes also chiseled. The specimen scanned by the $\mu$-CT does not display clear drilling traces. Our drilling experiment has shown that a calcium carbonate paste forms on the perforation on drilling, which may account for the absence of diagnostic traces.

\section{Use-Wear}

Worn artifacts are prevalent across nearly all raw materials (Supplemental Table 5). More than $70 \%$ of lithic ornaments are worn in contrast to about $15 \%$ of preforms and ornaments without use-wear. A different picture is observed for shell ornaments: more than $50 \%$ of the ornaments are worn, whereas $20 \%$ are unfinished or do not display use-wear. Because of the poor preservation of shell ornaments from El Cabo, use-wear could not be assessed on many specimens found there $(25.4 \%)$. The difference in the presence of use-wear in shell and lithic ornaments can also be related to the greater number of shell preforms. We observed a predominance of worn ornaments across all sites and nearly all morpho-technical groups (Table 3; Supplemental Table 4). Playa Grande is the only site where the percentage of worn ornaments does not reach $50 \%$. This is not surprising considering that it is the only site for which sustained evidence for ornament making is available.

\section{Discussion}

The particular trajectories of artifacts within each morpho-technical group help us understand ornament biographies at the sites and the 
different interaction spheres enabling their acquisition. Even though lithic raw materials tend to be locally available, the samples do not display evidence for local production of most morphotechnical groups. Production waste, blanks, and preforms are absent, and the lithic tools likely used for drilling and carving were not commonly recovered. Nevertheless, the presence of two lithic bead preforms at El Flaco and El Cabo shows that bead-making knowledge was present to some degree in these communities. In other words, most ornaments were brought into the sites already finished, despite the local availability of raw materials and the presumed existence of local bead-making knowledge. Nevertheless, Late Ceramic Age stone bead-making workshops, from where such finished beads could have come, are not known.

The final products and production sequences of certain lithic morpho-technical groups are quite similar, despite the use of raw materials such as calcite and plutonic rocks with different physical properties. A shared mental template and some degree of standardization were involved in the production of double-perforated beads, as suggested by the occurrence at all sites of specimens made with similar tools and on select raw materials. At the same time, instances of poor technical performance were commonly noted, including technical errors (Supplemental Table 4) and a lack of regularity in shape and size. Such variations in performance and resulting morphologies suggest, among others, a low level of standardization of production, a low level of craftsmanship, presence of apprentices, or a lack of care in production. Double-perforated beads occur across the Greater Antilles (e.g., Fewkes 2009 [1907]:109; García Castañeda 2012:71). Group 1 calcite beads are the most standardized and well distributed of all morpho-technical groups. Plutonic rock beads are more common at El Cabo than at El Flaco, where they are responsible for the larger variability in morpho-technical groups. By contrasting the most common bead groups in $\mathrm{El}$ Cabo and El Flaco, we can argue that there were different production centers, likely specializing in different raw materials and end products. Therefore, multiple production centers may have supplied beads to these communities. Bead groups that were only recovered from one site may be the result of local networks of artifact distribution.

Double perforated beads are of particular interest because it was previously speculated that the main perforation served for the insertion of feathers, whereas the bead was attached to a string composition through the side perforation (Fewkes 2009 [1907]:109). This traditional assumption is challenged by the use-wear distributions, which show that double perforated beads were assembled in a variety of compositions. For instance, beads with string-wear located exclusively on the main perforation were fairly common. These beads must have been strung exclusively along their longest axis; that is, as common beads. Evidence for the placement of adjacent beads or knots was also noted, in the form of deformed concavities on calcite beads. In contrast, 12 beads display string-wear on both length and side perforations; three such specimens also display evidence of a string being wrapped around the center of the bead, connecting the cones of the side perforation (Figure $4 \mathrm{p}$ ). Beads with strings passing along both axes may have served to connect multiple strands of an ornament. An anthropomorphic calcite bead displays black residue on one of its faces (Figure 4q) but no clear stringwear. The observed residue can be the result of an attachment string covered with residue or of an adhesive being used to fix something inside of the bead, such as a feather. Beads with stringwear exclusively on the side perforations, such as the two stalactite beads, would have hung asymmetrically, similarly to pendants.

Most lithic ornaments from Playa Grande do not fit the morpho-technical groups noted from the other sites. In particular, the plutonic rock beads from Playa Grande constitute a very diverse group in size, shape, and subtype. Four of these beads are preforms, whereas others display rather coarse surface treatments. Ear spools were also potentially made locally. Ornament production from lithic materials was taking place at the site, but it was not a specialized activity. Playa Grande did not provide other sites with lithic ornaments, in contrast to its known role as provider of greenstone celts to a wide region. Ornament production was likely connected to local use. 
In addition to "imported" lithic ornaments, the inland sites in the northwest of the Dominican Republic also yielded ornaments made of marine resources. We interpret this as evidence of multiple networks of ornament and/or material acquisition. Shell "seed bead" production centers have been identified in the Turks and Caicos, dated from around AD 1100-1300 (Carlson 1995; Keegan et al. 2008:645; Littman and Keegan 1991; Sinelli 2001:94). The sites were interpreted to be outposts in these small islands, specializing in the acquisition of $L$. gigas and C. sarda shells for large-scale bead making. Although these small beads could be used in necklaces, they are generally thought to be part of embroidered fabrics involving thousands of beads (Ostapkowicz 2013, 2018; Ostapkowicz et al. 2017). In the present study, we noted standardization in the production of "seed beads," in stark contrast with lithic beads and other shell ornaments. Therefore the "seed beads" recovered from El Flaco and El Cabo may have been obtained from workshops.

The shell bead production centers do not present evidence for the manufacture of the other shell ornaments we studied. As such, an alternative pattern of acquisition can be suggested. Evidence has been found for the local production of ornaments from marine resources at El Flaco (tinklers and coral beads), El Cabo (frog-shaped beads and plaques), and Playa Grande (biomorphic pendants and disc beads). In all cases, the production was of relatively small scale. It was likely not sufficient for local consumption, given that composite ornaments would have required numerous elements. This is clearer for tinklers, large numbers of which are believed to have hung in rattling bands tied around the arms and ankles of dancers (García Castañeda 2012:58; Lovén 1935:481). During use, it is likely that individual tinklers often broke because of collision with neighboring components. Locally produced tinklers may have served as replacements for repairing and thus extending the life of a rattling ornamental band. This reasoning can perhaps be extended to other forms of local production, with the possible exception of three-dimensional pendants. Large figurative pendants were likely central pieces around which composite ornaments were conceived. Diverse marine resources could be directly acquired by the inhabitants of the coastal sites of Playa Grande and El Cabo. The inhabitants of the northwestern sites were immersed in a regional network of villages located in different ecological niches (Hofman et al. 2018; Ulloa Hung 2013). Shells, corals, and fish skeletal materials were obtained directly or through exchange with people occupying mangrove or coastal sites and used as food resources, raw materials, and ornaments.

In sum, there was nonspecialized householdlevel production of ornaments in different raw materials at the three most extensively excavated sites. The difference between locally produced and imported ornaments did not correlate strictly to raw material variability (e.g., marine versus lithic resources). It was dependent on the specific trajectories of certain morpho-technical groups within each raw material. The depositional data also testify to the varied biographies of ornaments at these settlements.

\section{Deposition of Ornaments}

Most of the analyzed ornaments were not found in large groups or in closed contexts, which prevents us from assessing how composite body ornaments would have looked. At El Flaco, ornaments follow the pattern observed for other archaeological materials: they are found in the mound structures or adjacent to house structures. La Luperona and El Carril have thus far presented a similar picture. There is only one context from El Flaco where multiple beads were seemingly deposited as a group: 36 disc and barrelshaped calcite beads (groups 2 and 3) were recovered from the same square meter in a mound with burials and hearth structures but not in direct association with any one individual. Beads of these two morpho-technical groups have been found only at El Flaco and in very small numbers outside of this particular context. They were likely obtained as a group from a specific producing community. In this sense, the singularity of the two morpho-technical groups is also reflected in their singular deposition.

The majority of ornaments from El Cabo were retrieved from the southern excavation area, which was occupied from $\mathrm{AD} 800$ to about 1504. Some ornaments were recovered from 
postholes integrating 10 house plans, notably in entrance posts. This pattern arguably represented the ritual deposition of ornaments at the end of the life cycle of a house, before its abandonment and the construction of a new structure (Samson 2010, 2011). Other ornaments were recovered from the areas of greatest artifact density, following the same distribution pattern of most ceramic sherds and shell remains. The contrast between areas of dense artifact distribution and nearly clean areas was proposed to be due to the sweeping of refuse from the habitation areas toward the edge of the cliff (Samson 2010). The majority of ornaments found in Playa Grande were retrieved from activity areas associated with hearth structures or food preparation or from refuse middens (80.6\%). These areas date from AD 1000 to the early seventeenth century (López Belando 2012).

Most studied ornaments displayed use-wear and were deposited as the result of cleaning the house areas, rather than being deliberately added to hidden caches or burials. Beads can easily be lost, either by chance or by the restringing of composite ornaments. The fact that more than $70 \%$ of the sample is not fragmented suggests that these are not cases of intentional discard because of breakage. Integrating mounds and refuse areas, ornaments are the product of the regular maintenance of house areas as clean, functional, and desirable spaces. It may thus be suggested that ornaments reached the archaeological record as a result of their daily use at the sites, in the context of quotidian activities. Likewise, the importance of ornaments in daily life and the difficulty of their acquisition may be the reasons why they were not deposited with the dead, but perhaps were passed on to kin. Their homogeneous distribution throughout the sites can be regarded as an indication that the use of ornaments was widespread across all social categories. There may have been differential use according to social grouping, such as age and gender; nevertheless, these differences cannot be assessed through the data at hand. The small total amount of ornaments recovered from the sites highlights the concern with caring for and maintaining bodily ornaments, which limited their discard outside of prescribed deposition events such as closing rituals and hidden, perhaps votive, caches.

\section{Conclusion}

Archaeological debates concerning the adornment of the body in the Greater Antilles have focused on its role in reinforcing the political and religious power of high-status individuals. Little attention has been paid to demonstrating how people interacted with the commonly recovered ornament types. The present study applied for the first time an artifact biography approach to ornaments from Late Ceramic Age settlements. Our results show that bodily adornment cannot be taken for granted as a homogeneous category. First, a given ornament undergoes multiple changes during its lifetime-from raw material through production, circulation in networks of exchange, incorporation into composite ornaments, and eventual loss or discard. An ornament was dealt with in different ways in each life stage, and its status possibly evolved accordingly. Second, the morpho-technical groups had contrasting biographies, possibly as a result of their different expected social roles or of their participation in different social contexts. At the same time, the microwear study revealed how ornaments made of different materials or retrieved from different settlements shared certain biographical stages, such as material acquisition and production. Furthermore, our approach provided evidence for the circulation of ornaments and raw materials across different communities and regions. Future research focused on other sites is necessary to elucidate alternative ornament biographies and the interaction networks that encompassed them. Only then we will be able to more fully understand how ornaments were used in the establishment and negotiation of local and regional identities.

Acknowledgments. The authors acknowledge the Ministerio de la Cultura of the Dominican Republic and the Museo del Hombre Dominicano for granting permission to conduct this research. Furthermore, we would like to thank Jorge Ulloa Hung, Adolfo López Belando, the Torres family, Alice Knaf, Menno Hoogland, Darlene Weston, Eduardo Herrera Malatesta, Diederik Pomstra, Tom Breukel, and the students who assisted with the experiments. The present research was funded by the NWO Spinoza Prize awarded to Prof. Dr. Corinne L. Hofman in 2014. It is also part of the project NEXUS1492, which has received funding from the European Research Council under the European Union's Seventh Framework Programme (FP7/2007-2013)/ERC Grant agreement no. 319209 . 
Data Availability Statement. The Museo del Hombre Dominicano in Santo Domingo is the official repository of the collections studied in this research.

Supplemental Materials. For supplementary material accompanying this article, visit https://doi.org/10.1017/laq. 2019.101.

Supplemental Table 1. List of Experiments.

Supplemental Table 2. Ornament Raw Materials according to Archaeological Site.

Supplemental Table 3. Unfinished Ornaments Retrieved from the Studied Sites.

Supplemental Table 4. Technological and Use-Wear Data Collected for Each Morpho-Technical Group.

Supplemental Table 5. Use-Wear Presence according to Ornament Raw Material.

\section{References Cited}

Alegría, Ricardo E.

1995 La vestimenta y los adornos de los caciques Taínos y la parafernalia asociada a sus funciones mágico-religiosas. In Proceedings of the 15th International Congress for Caribbean Archaeology, edited by Ricardo E. Alegría and Miguel Rodríguez, pp. 295-310. Centro de Estudios Avanzados de Puerto Rico y el Caribe, San Juan.

Arrom, José J. (editor)

1975 Mitología e Artes Prehispánicas de las Antillas. Siglo XXI, Mexico City.

Balfet, Hélène (editor)

1991 Observer l'Action Technique: Des chaînes opératoires, pour quoi faire? Éditions du CNRS, Paris.

Berman, Mary Jane

2011 Good as Gold: The Aesthetic Brilliance of the Lucayans. In Islands at the Crossroads: Migration, Seafaring, and Interaction in the Caribbean, edited by Mark W. Hauser and L. Antonio Curet, pp. 104-134. University of Alabama Press, Tuscaloosa.

Bonnardin, Sandrine

2012 Parures de coquillages du Néolitique en Europe (VIe-Ve Millénaires av. J.-C.). Techniques \& Culture 59:26-43.

Breukel, Thomas W.

2019 Tracing Interactions in the Indigenous Caribbean through a Biographical Approach: Microwear and Material Culture across the Historical Divide (AD 1200-1600). PhD dissertation, Faculty of Archaeology, Leiden University, Leiden, Netherlands.

Breukel, Thomas W., and Catarina Guzzo Falci

2017 Experimental Reproduction of Wear Traces on Shell, Coral, and Lithic Materials from the Pre-Colonial Caribbean. In Proceedings of the 26th Congress of the International Association for Caribbean Archaeology, edited by Christopher B. Velasquez and Jay B. Haviser, pp. 146-167. Sint Maarten Archaeological Center (SIMARC), Sint Maarten.

Carlson, Lisabeth A.

1995 Strings of Command: Manufacture and Utilization of Shell Beads among the Taino. In Proceedings of the 15th International Congress for Caribbean Archaeology, edited by Ricardo E. Alegría and Miguel Rodríguez, pp. 97-109. Centro de Estudios
Avanzados de Puerto Rico y el Caribe, San Juan, Puerto Rico.

Cresswell, Robert

1983 Transferts de techniques et chaînes opératoires. Techniques \& Culture 2:143-159.

Cristiani, Emanuela, and Dusan Borić

2012 8500-Year-Old Late Mesolithic Garment Embroidery from Vlasac (Serbia): Technological, Use-Wear and Residue Analyses. Journal of Archaeological Science 39:3450-3469.

Curet, L. Antonio

1996 Ideology, Chiefly Power, and Material Culture: An Example from the Greater Antilles. Latin American Antiquity 7:114-131.

2014 The Taíno: Phenomena, Concepts, and Terms. Ethnohistory 61:467-495.

Draper, Grenville, Paul Mann, and John F. Lewis

1994 Hispaniola. In Caribbean Geology: An Introduction, edited by Stephen K. Donovan and Trevor A. Jackson, pp. 129-150. U.W.I. Publishers Association, Kingston, Jamaica.

Falci, Catarina Guzzo, Jacques Cuisin, André Delpuech, Annelou Van Gijn, and Corinne L. Hofman

2018 New Insights into Use-Wear Development in Bodily Ornaments through the Study of Ethnographic Collections. Journal of Archaeological Method and Theory 26:755-805.

Falci, Catarina Guzzo, Annelou Van Gijn, M. Magdalena Antczak, Andrzej T. Antczak, and Corinne L. Hofman

2017 Challenges for Microwear Analysis of Figurative Shell Ornaments from Pre-Colonial Venezuela. Journal of Archaeological Science: Reports 11:115-130.

Fewkes, J. Walter

1903 Precolumbian West Indian Amulets. American Anthropologist 5:679-691.

2009 [1907] The Aborigines of Porto Rico and Neighboring Islands. University of Alabama Press, Tuscaloosa.

García Castañeda, José A

2012 Ornamentos. Cuba Arqueológica 5(2):57-71.

Gosden, Chris, and Yvonne Marshall

1999 The Cultural Biography of Objects. World Archaeology 31:169-178.

Gu, Zhou, Jian Zhu, Yaoting Xie, Tiqiao Xiao, Yimin Yang, and Changsui Wang

2014 Nondestructive Analysis of Faience Beads from the Western Zhou Dynasty, Excavated from Peng State Cemetery, Shanxi Province, China. Journal of Analytical Atomic Spectrometry 29:1438-1443.

Helms, Mary W.

1987 Art Styles and Interaction Spheres in Central America and the Caribbean: Polished Black Wood in the Greater Antilles. In Chiefdoms in the Americas, edited by Robert D. Drennan and Carlos A. Uribe, pp. 67-83. University Press of America, Lanham, Maryland.

Hodder, Ian

2011 Human-Thing Entanglement: Towards an Integrated Archaeological Perspective. Journal of the Royal Anthropological Institute 17:154-177.

Hofman, Corinne L. (editor)

2017 Informe de Trabajo de Campo de 2017. Informe del 2017 sobre prospecciones y excavaciones a nivel intra sitio en la República Dominicana, por la Facultad de Arqueología de la Universidad de Leiden, Países Bajos, y NEXUS1492. Manuscript on file, Museo del Hombre Dominicano, Santo Domingo, Dominican Republic. 
Hofman, Corinne L., and Menno L. P. Hoogland

2015 Investigaciones arqueológicas en los sitios El Flaco (Loma de Gayacanes) y La Luperona (Unijica): Informe preliminar. Boletín del Museo del Hombre Domincano 46:61-74.

Hofman, Corinne L., Menno L. P. Hoogland, Alice V. M. Samson, and José R. Oliver

2008 Investigaciones arqueológicas en El Cabo, oriente de la República Dominicana: Resultados preliminares de las campañas 2005 y 2006. Boletín del Museo del Hombre Dominicano 42:307-316.

Hofman, Corinne L., Jorge Ulloa Hung, and Menno L. P. Hoogland

2016 El paisaje social indígena al momento del encuentro colonial: Nuevas investigaciones en el norte de la República Dominicana. Boletín del Museo del Hombre Dominicano 47:299-310.

Hofman, Corinne L., Jorge Ulloa Hung, Eduardo Herrera Malatesta, Joseph Sony Jean, Till Sonnemann, and Menno L. P. Hoogland

2018 Indigenous Caribbean Perspectives: Archaeologies and Legacies of the First Colonised Region in the New World. Antiquity 92:200-216.

Hofman, Corinne L., Angus A. A. Mol, Menno L. P. Hoogland, and Roberto Valcárcel Rojas

2014 Stage of Encounters: Migration, Mobility and Interaction in the Pre-Colonial and Early Colonial Caribbean. World Archaeology 46:590-609.

Hommel, Peter, and Margaret Sax

2014 Shifting Materials: Variability, Homogeneity and Change in the Beaded Ornaments of the Western Zhou. Antiquity 88:1213-1228.

Jones, Andrew

2004 Archaeometry and Materiality: Materials-Based Analysis in Theory and Practice. Archaeometry 46:327-338.

Joy, Jody

2009 Reinvigorating Object Biography: Reproducing the Drama of Object Lives. World Archaeology 41:540-556.

Keegan, William F.

2013 The "Classic" Taíno. In The Oxford Handbook of Caribbean Archaeology, edited by William F. Keegan, Corinne L. Hofman, and Reniel Rodríguez Ramos, pp. 70-83. Oxford University Press, Oxford.

Keegan, William F., Scott M. Fitzpatrick, Kathleen Sullivan Sealey, Michelle J. LeFebvre, and Peter T. Sinelli

2008 The Role of Small Islands in Marine Subsistence Strategies: Case Studies from the Caribbean. Human Ecology 36:635-654.

Keegan, William F., and Corinne L. Hofman

2017 The Caribbean before Columbus. Oxford University Press, Oxford.

Keehnen, Floris W. M.

2012 Trinkets (f)or Treasure? The Role of European Material Culture in Intercultural Contacts in Hispaniola during Early Colonial Times. Master's thesis, Faculty of Archaeology, Leiden University, Leiden, Netherlands.

Knippenberg, Sebastiaan

2012 Jadeitite Axe Manufacture in Hispaniola: A Preliminary Report on the Lithics from the Playa Grande Site, Northern Dominican Republic. Manuscript on file, Museo del Hombre Dominicano, Santo Domingo, Dominican Republic.

Kopytoff, Igor

1986 The Cultural Biography of Things: Commoditization as Process. In The Social Life of Things:
Commodities in Cultural Perspective, edited by Arjun Appadurai, pp. 64-91. Cambridge University Press, Cambridge.

Lammers-Keijsers, Yvonne M. J.

2007 Tracing Traces from Present to Past: A Functional Analysis of Pre-Columbian Shell and Stone Artefacts from Anse à la Gourde and Morel, Guadeloupe, FWI. Leiden University Press, Leiden, Netherlands.

Lemonnier, Pierre (editor)

1993 Technological Choices: Transformation in Material Cultures since the Neolithic. Routledge, London.

Leroi-Gourhan, André

1993 [1964] Gesture and Speech. MIT Press, Cambridge, Massachusetts.

Littman, Sherri L., and William F. Keegan

1991 A Shell Bead Manufacturing Center on Grand Turk, TCI. In Proceedings of the 14th International Congress for Caribbean Archaeology, edited by Alissandra Cummins and Philippa King, pp. 147-156. Barbados Museum and Historical Society, Bridgetown. López Belando, Adolfo J.

2012 El sitio arqueológico de Playa Grande, Río San Juan, María Trinidad Sánchez: Informe de las excavaciones arqueológicas campaña 2011-2012. Manuscript on file, Museo del Hombre Dominicano, Santo Domingo, Dominican Republic.

Lóven, Sven

1935 Origins of the Tainan Culture, West Indies. Elanders Boktryekeri Aktiebolag, Gothenburg, Sweden.

Maciques Sánchez, Esteban

2018 Idolillos colgantes de piedra en la cultura taína (Cuba). Edición Estudios Culturales 2003, Miami, Florida.

Malafouris, Lambros

2008 Beads for a Plastic Mind: The "Blind Man's Stick" (BMS) Hypothesis and the Active Nature of Material Culture. Cambridge Archaeological Journal 18:401-414.

Mărgărit, Monica

2016 Testing the Endurance of Prehistoric Adornments: Raw Materials from the Aquatic Environment. Journal of Archaeological Science 70:66-81.

Martiñón-Torres, Marcos, Roberto Valcárcel Rojas, Juanita Sáenz Samper, and María Filomena Guerra

2012 Metallic Encounters in Cuba: The Technology, Exchange and Meaning of Metals before and after Columbus. Journal of Anthropological Archaeology 31:439-454.

McGinnis, Shirley A. M.

1997 Ideographic Expression in the Precolumbian Caribbean. PhD dissertation, Department of Anthropology, University of Texas, Austin.

Ngan-Tillard, Dominique J. M., Dirk J. Huisman, Francesca Corbella, and Annelot Van Nass

2018 Over the Rainbow? Micro-CT Scanning to NonDestructively Study Roman and Early Medieval Glass Bead Manufacture. Journal of Archaeological Science 98:7-21.

Oliver, José R.

2000 Gold Symbolism among Caribbean Chiefdoms: Of Feathers, Çibas and Guanín Power among Taíno Elites. In Precolumbian Gold: Technology, Style and Iconography, edited by Colin McEwan, pp. 196-219. British Museum Press, London.

2009 Caciques and Cemi Idols: The Web Spun by Taíno Rulers between Hispaniola and Puerto Rico. University of Alabama Press, Tuscaloosa. 
Ortega, Elpídio J.

1978 Informe sobre investigaciones arqueológicas realizadas en la región este del país, zona costera desde Macao a Punta Espada. Boletín del Museo del Hombre Dominicano 11:77-205.

2005 Compendio General Arqueológico de Santo Domingo, Vol. 1. Academia de Ciencias de la República Dominicana, Santo Domingo.

Ortega, Elpídio J., and Carmen G. Fondeour

1976 Primer informe sobre piezas metalicas indígenas en Barrera. Cuadernos del Cendia 254:1-10.

Ostapkowicz, Joanna

2013 "Made . . . with Admirable Artistry": The Context, Manufacture and History of a Taíno Belt. Antiquaries Journal 93:287-317.

2018 To Produce "A Pleasing Effect": Taíno Shell and Stone Cibas and Spanish Cuentas in the Early Colonial Caribbean. Beads 30:3-15.

Ostapkowicz, Joanna, Fiona Brock, Alex C. Wiedenhoeft, Rick Schulting, and Donatella Saviola

2017 Integrating the Old World into the New: An "Idol from the West Indies.” Antiquity 91:1314-1329.

Perlès, Catherine

2007 Échanges et Technologie: L'exemple du Néolithique. In Un Siècle de Construction du Discours Scientifique en Préhistoire, Vol. III, edited by Jacques Évin, pp. 53-62. Société Préhistorique Française, Paris.

Rodríguez Ramos, Reniel

2010 Rethinking Puerto Rican Precolonial History. University of Alabama Press, Tuscaloosa.

Rouse, Irving B.

1992 The Tainos: Rise and Decline of the People Who Greeted Columbus. Yale University Press, New Haven, Connecticut.

Samson, Alice V. M.

2010 Renewing the House: Trajectories of Social Life in the Yucayeque (Community) of El Cabo, Higüey, Dominican Republic, $A D 800$ to 1504. Sidestone Press, Leiden, Netherlands.

2011 The Most Beautiful House in the World: The Archaeology of Aesthetics in Eastern Hispaniola. In Communities in Contact: Essays in Archaeology, Ethnohistory and Ethnography of the Amerindian CircumCaribbean, edited by Corinne L. Hofman and Anne van Duijvenbode, pp. 421-438. Sidestone Press, Leiden, Netherlands.

Samson, Alice V. M., and Menno L. P. Hoogland

2007 Residencia Taína: Huellas de asentamiento en El Cabo, República Dominicana. El Caribe Arqueológico 10:93-103.

Saunders, Nicholas J.

1999 Biographies of Brilliance: Pearls, Transformations of Matter and Being, c. AD 1492. World Archaeology 31:243-257.

Schertl, Hans-Peter, Walter V. Maresch, Sebastiaan Knippenberg, Andreas Hertwig, Adolfo López Belando, Reniel Rodríguez Ramos, Laura Speich, and Corinne L. Hofman

2018 Petrography, Mineralogy and Geochemistry of Jadeite-Rich Artefacts from the Playa Grande Excavation Site, Northern Hispaniola: Evaluation of Local Provenance from the Río San Juan Complex. Geological Society Special Publications No 474. Geological Society, London.

Siegel, Peter E.

2010 Continuity and Change in the Evolution of Religion and Political Organization on Pre-Columbian Puerto Rico. Journal of Anthropological Archaeology 29:302-326

Sillar, Bill, and, Michael S. Tite

2000 The Challenge of Technological Choices for Materials Science Approaches in Archaeology. Archaeometry 42:2-20.

Sinelli, Peter T.

2001 Archaeological Investigations of Two Prehistoric Sites Representing a Hispaniolan Colonization of Middle Caicos, Turks and Caicos Islands. Master's thesis, Department of Anthropology, University of Florida, Gainesville.

Sonnemann, Till F., Jorge Ulloa Hung, and Corinne L. Hofman

2016 Mapping Indigenous Settlement Topography in the Caribbean Using Drones. Remote Sensing 8(10):791.

Torres Etayo, Daniel

2008 En busca del Taíno, historia de una pelea cubana contra el normativismo. Cuba Arqueológica 1:6-17.

Ulloa Hung, Jorge

2013 Arqueología en la Linea Noroeste de La Española. Paisaje, cerámicas e interacciones. $\mathrm{PhD}$ dissertation, Faculty of Archaeology, Leiden University, Leiden, Netherlands.

Ulloa Hung, Jorge, and Eduardo Herrera Malatesta

2015 Investigaciones arqueológicas en el norte de La Española, entre viejos esquemas y nuevos datos. Boletín del Museo del Hombre Dominicano 46:75-107.

Valcárcel Rojas, Roberto

2012 Interacción colonial en un pueblo de indios encomendados: El Chorro de Maíta, Cuba. PhD dissertation, Faculty of Archaeology, Leiden University, Leiden, Netherlands.

Van Gijn, Annelou

2010 Flint in Focus: Lithic Biographies in the Neolithic and Bronze Age. Sidestone Press, Leiden, Netherlands.

2017 Bead Biographies from Neolithic Burial Contexts: Contributions from the Microscope. In Not Just for Show: The Archaeology of Beads, Beadwork, and Personal Ornaments, edited by Daniella Bar-Yosef Mayer, Clive Bonsall, and Alice M. Choyke, pp. 103 114. Oxbow Books, Oxford.

Van Gijn, Annelou, and Karsten Wentink

2013 The Role of Flint in Mediating Identities: The Microscopic Evidence. In Mobility, Meaning and Transformations of Things: Shifting Contexts of Material Culture through Time and Space, edited by Hans Peter Hahn and Hadas Weiss, pp. 120-132. Oxbow Books, Oxford.

Vanhaeren, Marian, Francesco d'Errico, Karen L. van Niekerk, Christopher S. Henshilwood, and Rudolph M. Erasmus

2013 Thinking Strings: Additional Evidence for Personal Ornament Use in the Middle Stone Age at Blombos Cave, South Africa. Journal of Human Evolution 64:500-517.

Vega, Bernardo

1979 Los metales y los aborígenes de la Hispaniola. Ediciones Museo del Hombre Dominicano, Santo Domingo, Dominican Republic.

Veloz Maggiolo, Marcio, and Elpídio J. Ortega

1980 Nuevos hallazgos arqueológicos en la costa norte de Santo Domingo. Boletín del Museo del Hombre Dominicano 13:11-48. 
Veloz Maggiolo, Marcio, Elpídio J. Ortega, and A. Caba 1981 Los modos de vida Meillacoides y sus posibles orígenes. Editora Taller, Santo Domingo, Dominican Republic.

Wilson, Samuel M.

1993 The Cultural Mosaic of the Indigenous Caribbean. Proceedings of the British Academy 81:37-66.

2007 The Archaeology of the Caribbean. Cambridge University Press, Cambridge.

Woodward, Ann

2002 Beads and Beakers: Heirlooms and Relics in the British Early Bronze Age. Antiquity 76:1040-1047.
Woodward, Ann, and John Hunter

2015 Ritual in Early Bronze Age Grave Goods. Oxbow Books, Oxford.

Yang, Yimin, Chunxue Wang, Xing Gao, Zhou Gu, Ning Wang, Tiqiao Xiao, and Changsui Wang

2018 Micro-CT Investigation of Ostrich Eggshell Beads Collected from Locality 12, the Shuidonggou Site, China. Archaeological and Anthropological Sciences 10:305-313.

Submitted February 12, 2019; Revised August 24, 2019; Accepted December 5, 2019 